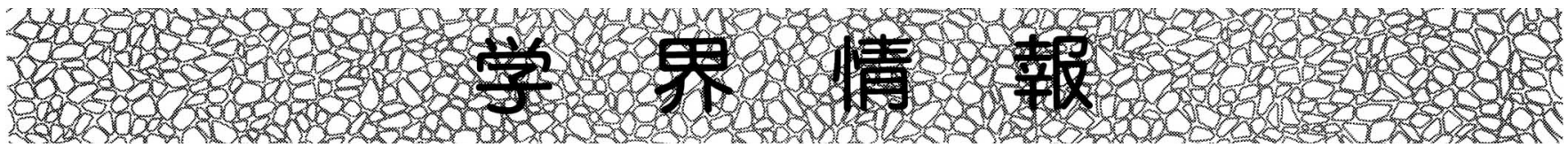

\title{
IEEE PES 2010 TRANSMISSION AND DISTRIBUTION CONFERENCE AND EXPOSITION 参加報告
}

1. はじめに

IEEE Power and Energy Society (PES) 主催の

Transmission and Distribution Conference and Exposition 2010（T\&D2010）が，2010 年 4 月 19 日（月） 〜 月 22 日（木）に米国ルイジアナ州ニューオーリンズの Ernest N. Morial Convention Center で開催された。T\&Dは，IEEE PES が主催する会議の中でも夏の General Meeting に匹敵 するほどの大きな会議で，特に大規模な展示会が併設され ることで知られる。2 年に一回開催されるが，最近はそれと は別に T\&D のアジア版や南米版も開催されている。内容は 会議名にもあるように送電・配電関係ということになるが， 実際には電力・エネルギー全般にわたるといった印象を受 けた。

\section{2. 会議の状況}

T\&D2010 のテーマは Smart Solutions for a Changing World である。すなわち本会議では（展示も含め）米国を 中心として世界中で盛り上がる Smart Grid のムーブメン 卜に呼応するかのように，送配電システムを高いレベルで 運転・維持するための手法を技術面・ビジネス面で評価す ること, さらには参加者にケーススタディや実施事例など 有益な話題を提供することを目的としていた。会議の主な スコープ（論文募集の技術分野）は次のとおりである。

$\checkmark$ スマートグリッド，その通信とサイバーセキュリティ

$\checkmark$ 再生可能エネルギーの統合

$\checkmark$ 温室ガス削減, エネルギー効率利用, 環境面での品 質向上のためのプログラム

$\checkmark \quad$ 風力発電の統合と電力ピークカットのためのエネル ギー貯蔵システム

$\checkmark$ 安全，メンテナンス，運転を優先した文化の開発

$\checkmark$ 停電や電圧崩壊を防止するための送電システム信頼 性の向上

$\checkmark$ 新しい設計による送配電システム信頼性の向上

$\checkmark$ 配電システム系統と需要家システムの設計・運転の 改良による電力品質の向上

セッションは大きくパネル, ポスター, チュートリアル などに分けられる。開会式と同じ大会場で開かれる大規模 なパネルセッションはスーパーセッションと呼ばれるが, 本大会のスーパーセッションは下記の 4 件であった。

$\checkmark \quad$ Energy Storage and the Integration of Renewables

$\checkmark \quad$ Smart Grid

$\checkmark \quad$ Cyber Security of T\&D Control System Assets

$\checkmark \quad$ Cap and Trade and Its Impact on the Electric Utility Industry
会期中の一日（4月 21 日）は Smart Grid Day と題され, すべてのセッションが Smart Grid 関係で占められた。筆者 が発表（論文タイトルは A High Quality Power Supply System with DC Smart Grid）を行ったパネルセッション Smart Grid Issues もこの日にあった。

展示場では韓国の展示が印象に残った。ブースの大きさ, コンパニオンの服装などたとえば日本企業の展示に比べて もはるかに派手な印象であった。また，有名企業の大きな ブースだけでなく, 複数企業がまとまってコンソーシアム として展示をしているのが印象に残った。個々のブースは 小さくても全体として迫力がある。

\section{3. 雑 感}

ニューオーリンズといえば思い出されるのが 2005 年八 リケーン・カトリーナによる大被害である。確か 2005 年に もニューオーリンズでの T\&D が計画されていたがハリケ ーン被害の影響で他の場所に変更になった。今回 T\&D2010 に参加できることになり，ニューオーリンズがあのハリケ ーン被害から完全に復旧しているのかどうか自分の目で確 かめたかった。空港から市内に向から際に We are jazzed, we are here の看板を見た。これは完全復旧を謳っているの かなと胸が熱くなった。また，さらにその感を強くしたの が初日の夕方に行われた Welcome Party である。これは筆 者がこれまで参加したどの国際会議のものよりも豪華なパ ーティーだった。

ミシシッピ川のほとりにある水族館を貸切にし，庭には ガンボスープやジャンバラヤなどルイジアナ名物のブース が並ぶ。4 つのステージではジャズやケイジャン, R\&B な ど南部っぽい音楽がライブで演奏され，会場内をマルディ グラのお祭りを髣鬌とさせるブラスバンドが練り歩く。最 後はミシシッピ川に 15 分間の花火があがった。このもてな しを見て筆者はニューオーリンズの復旧を確信した。ただ， 後に他の参加者から聞いたところでは会議のテクニカルツ アーのひとつとしてボランティアで被害家屋の復旧を手伝 うというものがあった。筆者はホテルのあるフレンチ・ク オーターと会場とを往復するだけで郊外の状況までは見る ことができなかったが，まだまだ被害は残っているのであ る。

\section{4. おわりに}

T \& D 2012 は米国フロリダ州 Orlando で開催される。そ の頃 Smart Grid の開発は一段落しているだろうか。二年後 にどんなサブタイトルが付けられるのか楽しみである。

舟橋 俊久 (明電舎)

(平成 22 年 6 月 23 日受付) 